that each of the multiple copies of RD-114 or FeLV-related virogenes occurs on a different linkage group, as well as models of non-chromosomal inheritance of the multiple viral copies.

Since only certain Felis species contain RD-114 and FeLVrelated sequences in their DNA, we propose that both classes of viruses were acquired by cats subsequent to their major radiation, most likely in the Pliocene, and that both sets of sequences have been perpetuated in the germ line ${ }^{9,16}$. The multiple virogene copies presumably arose as a result of gene duplication and/or unequal crossing-over after infection. The presence of multiple copies of both sets of virogenes in cat cellular DNA seems to be a general property of endogenous mammalian type $\mathrm{C}$ viruses; mouse, rat, hamster, pig and baboon DNAs also contain similar numbers of copies of their respective endogenous viruses ${ }^{19}$.

The genetic crosses described here provide a new approach to the study of the evolution of multiple gene systems. The virogene sequences can be considered as one of the group of moderately repetitive sequences such as the genes for $5 \mathrm{~S}$ RNA $^{25}$, histones ${ }^{26}$ and feather keratin ${ }^{20}$. The existence of natural populations of animals that either lack or contain DNA sequences related to both RD-114 and FeLV, and the ability of these cats to interbreed permits the study of the physiological and potentially pathological role of each of these genetically transmitted gene sequences. Hybrid animals containing half the number of virogene copies and virogenenegative cats should allow the study of the effects of gene dose on susceptibility and resistance to diseases mediated by both groups of type C viruses.

We thank J. Koci and G. L. Wilson for assistance, and R. Callahan and C. Sherr for comments and discussion. Supported in part by the Virus Cancer Program of the National Institutes of Health.

Raoul E. Benveniste GEORGE J. TODARO

Viral Leukemia and Lymphoma Branch,

National Cancer Institute,

National Institutes of Health,

Bethesda, Maryland 20014

Received June 30; accepted August 26, 1975.

1 McAllister, R. M., et al., Nature new Biol., 235, 3 6(1972).

2 Livingston, D. M., and Todaro, G. J., Virology, 53, 142-151 (1973).

Fischinger, P. J., Peebles, P. T., Nomura, S., and Haapala, D. K., J. Virol., 11, 978-985(1973).

Todaro, G. J., Benveniste, R. E., Lieber, M. M., and Livingston, D. M., Virology, 55, $505-515(1973)$

5 Baluda, M. A., and Roy-Burman, P., Nature new Biol., 244, 59 62 (1973),

6 Neiman, P. E., Nature new Biol, 244, 62-64 (1973).

Gillespie, D., Gillespie, S., Gallo, R. C., East, J. L., and Dmochowski, L. Nature new Biol. 244,51-54(1973).

Ruprecht, R. M., Goodman, N. C., and Spiegelman, S., Proc. natn. Acad. Sci., U.S.A., 70, 1437-1441 (1973).

9 Benveniste, R. E., and Todaro, G. J., Nature, 252, 456-459 (1974). G. J.,J.Virol., i4, 56-67 (1974).

11 Sherr, C. J., and Todaro, G. J., Virology, 61, 168-181 (1974).

12 Todaro, G. J., Benveniste, R. E., Callahan, R., Lieber, M. M., and Sherr, C. J., in Cold Spring Harb. Symp. quant. Biol., 39, 1159-1168 (Cold Spring Harbo in Cold Spring Harb. Symp. quant. Biol., 39,

13 Benveniste, R. E., and Todaro, G. J., Proc, natn. Acad. Sci. U.S.A., 71, 4513-4518 (1974)

4 Jarrett, W. F. H., Crawford, E. M., Martin, W. B., and Davie, F., Nature, 202, 567-568 (1964)

15 Quintrell, N., Varmus, H. E., Bishop, J. M., Nicholson, M. O., and McAllister, R. M., Virology, 58, 568-575 (1974).

16 Benveniste, R. E., Sherr, C. J., and Todaro, G. J., Science (in the press).

17 McCarthy, B. J., and Farquhar, M. N., in Evolution of Genetic Systems (edit. by Smith, H. H.), 1-43 (Gordon and Breach, New York, 1972).

Wetmur, J. G., and Davidson, N., J. molec. Biol., 31, 349-370 (1968).

Benveniste, R. E., and Todaro, G. J., Nature, 252, 170-173 (1974).

Kemp, D. J., Nature, 254, 573-577 (1975)

Bonner, T. I.. Brenner, D. J., Neufeld, B. R., and Britten, R. J., J. molec. Biol., 81, 123-135(1973)

Rickard, C. G., Post, J. E., Noronha, F., and Barr, L. M., J. natn. Cancer Inst., 42, 987-1014 (1969)

3 Gardner, M. B., Arnstein, P., Johnson, E., Rongey, R. W., Charman, H. P., and Huebner, R. J., J. Am. vet. Med. Ass., 158, 1046-1053 (1971).

Benveniste, R. E., and Todaro, G. J., Proc. natn. Acad. Sci. U.S.A., 70, 3316 3320 (1973).

25 Brown, D. D., Wensink, P. C., and Jordan, E., Proc. natn. Acad. Sci. U.S.A., $68,3175-3179(1971)$

26 Kedes, L. H., and Birnsteil, M. L., Nature new Biol., 230, 165-169(1971).

27 Benveniste, R. E., and Scolnick, E. M., Virology, 51, 370-382 (1973).

28 Britten, R. J., and Kohne, D. E., Science, 161, 529 540(1968)

. $117-127$ (1975).

\section{Identification of heat-dissociable RNA complexes in two porcine coronaviruses}

THE coronavirus genome has been shown to comprise singlestranded RNA $^{1,2}$. Examination of the viral nucleic acid synthesised by pig kidney cells infected with transmissible gastroenteritis virus (TGEV) suggested that several molecular species, ranging in size between 18 and $28 \mathrm{~S}$, were involved in the viral replicative cycle ${ }^{3}$; similarly Tannock found a wide variation in the size of RNA molecules extracted from avian infectious bronchitis virus (IBV) by a phenol-sodium dodecyl sulphate (SDS) method ${ }^{2}$. Extraction of IBV RNA by $1 \%$ SDS at $60^{\circ} \mathrm{C}$ has, however, revealed a single component of molecular weight $9 \times 10^{6}$ corresponding to $60 \mathrm{~S}$ by electrophoresis through $2.2 \%$ polyacrylamide gels ${ }^{4}$.

We have examined the RNA extracted from purified preparations of TGEV and a second porcine coronavirus -haemagglutinating encephalomyelitis virus (HEV)-and have found a 60-70S RNA component which dissociates into $35 \mathrm{~S}$ and $4 \mathrm{~S}$ material on heating above $60^{\circ} \mathrm{C}$ in a way that closely resembles the genome of the oncogenic RNA viruses.

We had observed that treatment of purified TGEV with $1 \%$ SDS at $20^{\circ} \mathrm{C}$ disrupted the virions and liberated a high molecular weight complex containing the RNA. On the assumption that this complex might comprise the hitherto undetected ribonucleoprotein, we extracted the material from TGEV preparations radioactively labelled with ${ }^{3} \mathrm{H}$ uridine or with ${ }^{3} \mathrm{H}$-leucine to determine which structural polypeptide was associated with the complex. As is shown in Fig. 1, however, the fast moving RNA complex has no detectable protein associated with it, while polyacrylamide gel analysis of the radioactivity remaining near the top of

Fig. 1 Rate zonal sedimentation of TGEV after treatment with $1 \%$ SDS at $20^{\circ} \mathrm{C}$. TGEV was grown in secondary pig thyroid cell (APT/2) cultures in the presence of $5-^{3} \mathrm{H}$-uridine (O) or 4,5${ }^{3} \mathrm{H}$-leucine ( ) and purified by sucrose gradient centrifugation as described previously ${ }^{5}$. After treatment with $1 \% \mathrm{SDS}$ at $20{ }^{\circ} \mathrm{C}$ for $15 \mathrm{~min}$, each preparation was layered over a $6-\mathrm{ml} 15-30 \%(\mathrm{w} / \mathrm{w})$ sucrose gradient and centrifuged at $250,000 \mathrm{~g}$ for $2 \mathrm{~h}$ in a swing-out rotor. The gradients were fractionated by siphon and total radioactivity was determined for each fraction.

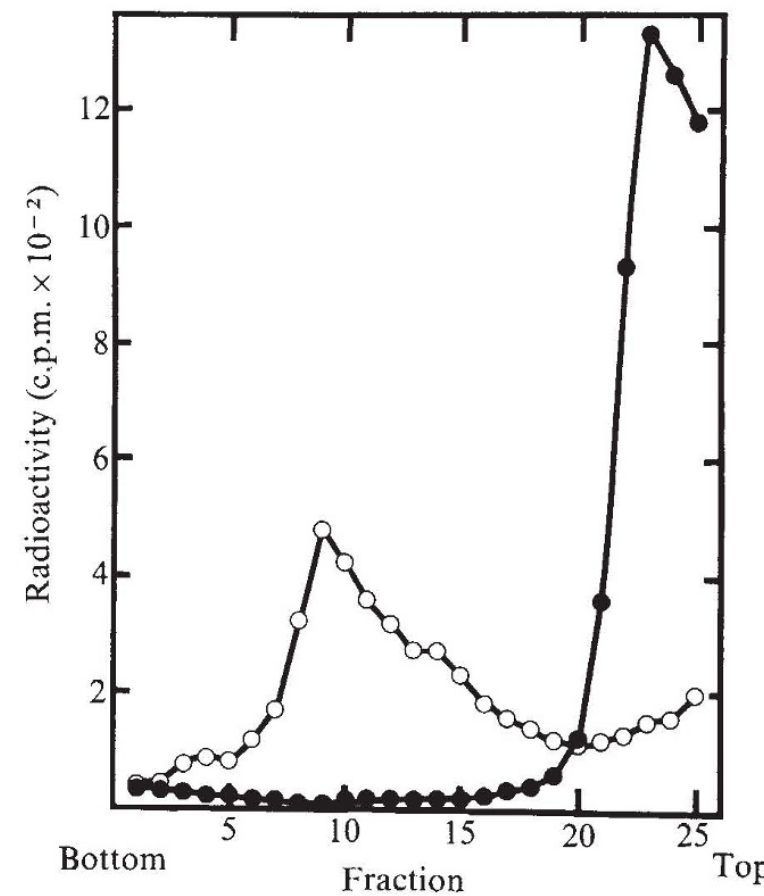


the gradient demonstrated the presence of viral structural polypeptides ${ }^{5}$.

Extraction of RNA from ${ }^{3} \mathrm{H}$-uridine-labelled TGEV by $1 \% \mathrm{SDS}$ at $20^{\circ} \mathrm{C}$ followed by electrophoresis through gels containing $2 \%$ polyacrylamide and $0.6 \%$ agarose revealed a homogeneous band of high molecular weight RNA and a very small amount of radioactivity in the area of the marker dye, corresponding to approximately 4-7S (Fig. 2a). Similar extractions were performed on replicate virus samples using $1 \% \operatorname{SDS}$ at $40,60,80$ and $100{ }^{\circ} \mathrm{C}$ and the released RNA was electrophoresed as before. The electrophoretograms illustrated in Fig. $b-e$ showed that the mobility of the major RNA band increased slightly as the extraction temperature was raised to $60^{\circ} \mathrm{C}$ and, while the homogeneity of the leading edge of the band decreased somewhat, there was no obvious change in the $4 \mathrm{~S}-7 \mathrm{~S}$ region. As the temperature was increased through 80 to $100{ }^{\circ} \mathrm{C}$, however, the radioactivity became associated with a broader band of RNA, whose mobility was at least twice that of the RNA extracted at lower temperatures, and there was an increase in the amount of RNA in the $4 \mathrm{~S}$ region of the gel.

This apparent "melting" of the high molecular weight complex into smaller components with the liberation of $4 \mathrm{~S}$

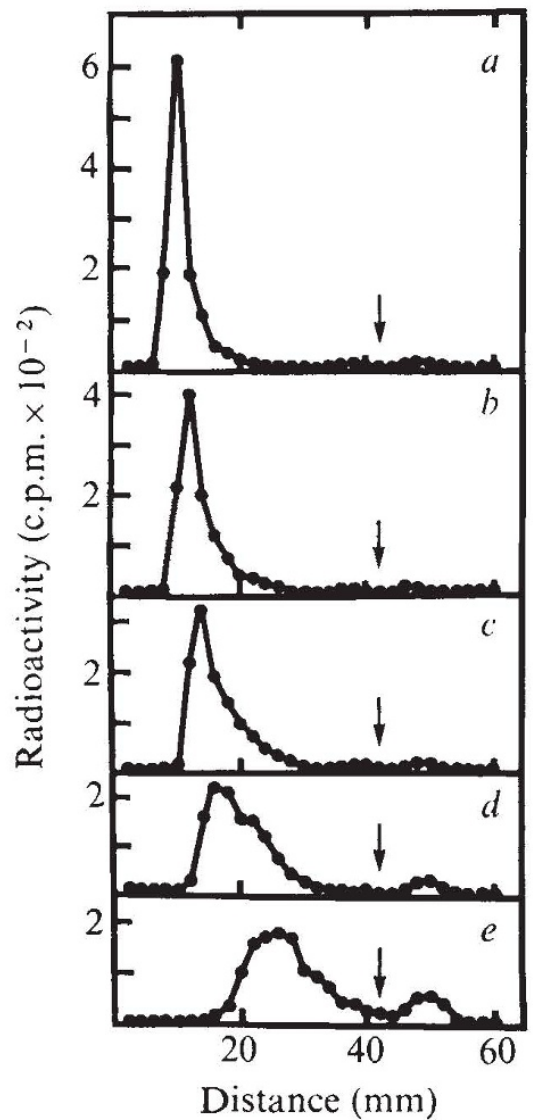

Fig. 2 Gel electrophoresis of TGEV RNA following extraction in $1 \%$ SDS at various temperatures. TGEV was grown in APT $/ 2$ cultures in the presence of $5-{ }^{3} \mathrm{H}$-uridine and purified by sucrose gradient centrifugation. The preparation was suspended in $L$ buffer (36 mM 2-amino-2-hydroxymethylpropane-1,3-diol (Tris); $30 \mathrm{mM} \mathrm{NaH}_{2} \mathrm{PO}_{4} ; 1 \mathrm{mM}$ ethylenediaminetetraacetic acid (EDTA); $p \mathrm{H} \mathrm{7.8)} \mathrm{and} \mathrm{SDS} \mathrm{was} \mathrm{added} \mathrm{to} 1 \%$ at $20^{\circ} \mathrm{C}$. The suspension was divided into five parts and each part was held in a water bath at $20(a), 40(b), 60(c), 80(d)$ or $100^{\circ} \mathrm{C}(e)$ for 30 $\mathrm{min}$. After cooling, sucrose was added to $5 \%(\mathrm{w} / \mathrm{w})$ and bromophenol blue was added as a marker dye, each sample was layered over a $6 \times 60 \mathrm{~mm} 2 \%(\mathrm{w} / \mathrm{v})$ polyacrylamide $/ 0.6 \%$ agarose $\mathrm{gel}^{6}$ and electrophoresed for $1 \mathrm{~h}$ at $8 \mathrm{~mA}$ per gel using $\mathrm{L}$ buffer containing $0.2 \% \mathrm{SDS}$. The gels were sliced into $1-\mathrm{mm}$ fractions and the radioactivity of each slice was determined in a toluene-Triton X-100 scintillant. The location of the marker dye was estimated by eye and is represented by the arrows.

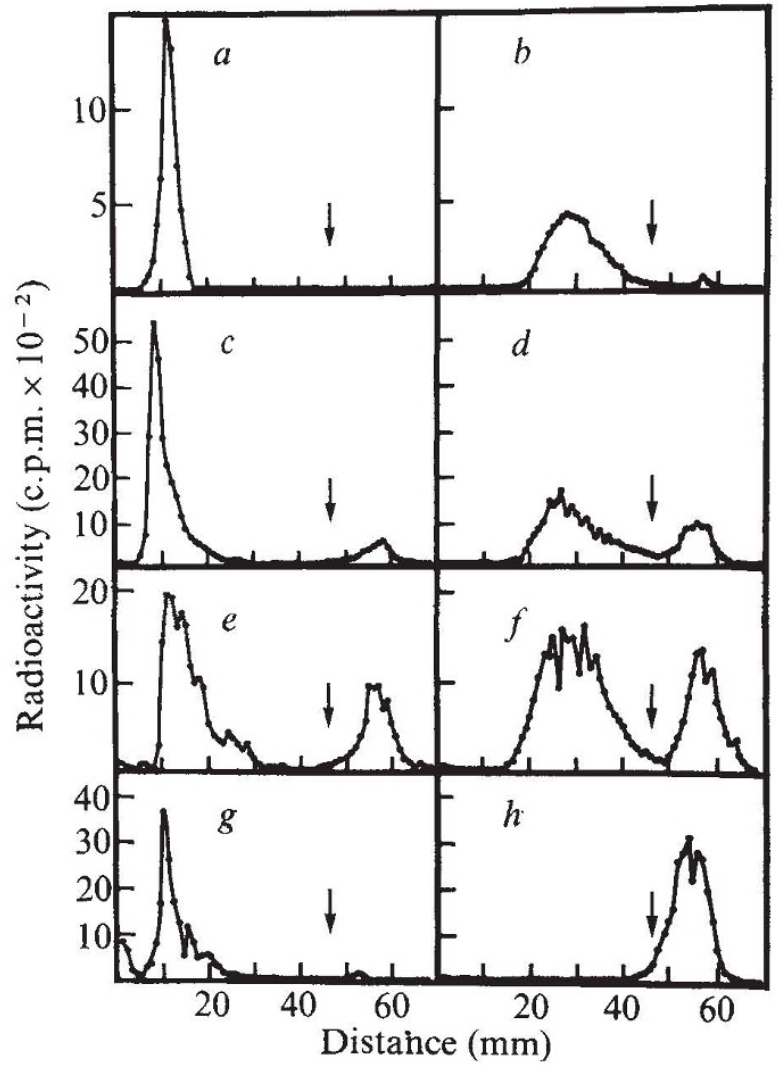

Fig. 3 Gel electrophoresis of RNA from RSV, TGEV, and HEV. TGEV and HEV weregrown in APT/2 and primary pig kidney cell cultures respectively in medium containing $5{ }^{3} \mathrm{H}$-uridine. Both viruses were purified by sucrose gradient centrifugation and suspended in $\mathrm{L}$ buffer. After $24 \mathrm{~h}$ at $4{ }^{\circ} \mathrm{C}$ or, in the case of the virus used in $(g)$ and $(h)$, after $20 \mathrm{~d}$ at $4{ }^{\circ} \mathrm{C}$, SDS was added to $1 \%$ and the preparations were held at 20 or $100{ }^{\circ} \mathrm{C}$ for $30 \mathrm{~min}$. Purified 60-70S RNA from RSV was held in $10 \mathrm{mM} \mathrm{NaCl} ; 8 \mathrm{mM}$ Tris; $7 \mathrm{mM} \mathrm{NaH} \mathrm{PO}_{4} ; 1 \mathrm{mM}$ EDTA; $1 \% \mathrm{SDS} ; p \mathrm{H} 7.8$ at 20 and $100{ }^{\circ} \mathrm{C}$ for the same length of time. The preparations were cooled to $20^{\circ} \mathrm{C}$, sucrose and bromophenol blue were added and electrophoresis and fractionation were conducted as described for Fig. 2, using $6 \times 70 \mathrm{~mm}$ gels. RSV RNA held at $20(a)$, and $100^{\circ} \mathrm{C}$ (b) ; TGEV extracted at $20(c)$, and $100^{\circ} \mathrm{C}(d)$ after $24 \mathrm{~h}$ at $4{ }^{\circ} \mathrm{C}$; HEV extracted at $20(e)$, and $100^{\circ} \mathrm{C}(f)$ after 24 h at $4^{\circ} \mathrm{C}$; TGEV extracted at $20(\mathrm{~g})$ and $100^{\circ} \mathrm{C}(h)$ after $20 \mathrm{~d}$ at $4{ }^{\circ} \mathrm{C}$. The arrows denote the location of the marker dye.

RNA at temperatures above $60^{\circ} \mathrm{C}$ closely resembles the findings for the oncogenic RNA viruses? ${ }^{7}$. To determine the size of the coronaviral RNA components and their similarity to oncornaviral RNA, we compared the mobilities of RNA extracted from TGEV and HEV at 20 and $100^{\circ} \mathrm{C}$ with those of purified Rous sarcoma virus (RSV) RNA held at the same temperatures. Figure $3 a-f$ shows that, by this method, the RNA complexes extracted from the two coronaviruses are indistinguishable in size from the 60-70S component of RSV RNA and that, after heating, the TGEV and HEV RNA components are comparable in size to the RSV 35S RNA. There seems to be more heterogeneity in the coronaviral 35S RNA band than in the RSV equivalent and this holds true regardless of the time of the labelling period. Comparison of RNA extracted from TGEV labelled with ${ }^{3} \mathrm{H}$-uridine $0-4,4-8,8-12,12-16$ or $0-20 \mathrm{~h}$ after infection shows that, although the total radioactivity incorporated varied with the time of labelling period, the overall shape of the RNA curves after extraction at 20 and $100^{\circ} \mathrm{C}$ were similar. This difference in heterogeneity may be due partly to the fact that we were comparing extracts from whole HEV and TGEV with purified 60-70S RNA from RSV, but it may also be caused by partial degradation of the RNA within the virion. That this undoubtedly occurs is demonstrated by the electrophoretograms illustrated in Fig. $3 g-h$, which were all derived 
from TGEV that had been held at $4{ }^{\circ} \mathrm{C}$ for $20 \mathrm{~d}$ before extraction at 20 and $100{ }^{\circ} \mathrm{C}$ in $1 \%$ SDS. The $60-70 \mathrm{~S}$ complex seems to be intact, but, on melting, the complex liberates only small fragments of RNA of approximately $4 \mathrm{~S}$ (Fig. 3h). This suggests that the virus preparations have an associated ribonuclease capable of producing breaks in the $35 \mathrm{~S}$ strand while they are complexed in the 60-70S form. Whether the large amount of 4S RNA detected in all HEV preparations so far examined (Fig. $3 e-f$ ) represents degraded viral RNA or host tRNA associated with the virions is not known.

Our inability to detect protein in the 60-70S RNA complex from TGEV does not exclude the possibility that there is a very small amount that is dissociating from the RNA at elevated temperatures in the presence of SDS. The similarity of behaviour and size between the coronaviral RNA and RSV RNA, together with the liberation of $4 \mathrm{~S}$ RNA on melting suggests strongly that the TGEV and HEV 60-70S complex is held together by RNA-RNA interactions as is the RNA from oncornaviruses. We hope to characterise further the 60-70S complex and determine whether the viral $4 \mathrm{~S}$ component is in fact host tRNA. Although the replication of these two groups of viruses is fundamentally different, the coronaviruses being entirely cytoplasmic in contrast to the essential nuclear phase of the oncornaviruses, a similarity in the structure of the genomes of the two groups raises interesting implications for the phylogeny of the RNA tumour viruses.

We thank Mrs Brenda V. Pike for assistance and Dr S. Martin, Imperial Cancer Research Fund Laboratories, London, for the gift of ${ }^{3} \mathrm{H}$-uridine-labelled RSV RNA. One of us (T.M.W.) was in receipt of a British Council Scholarship.

\section{J. Garwes \\ D. H. POCOCK}

Department of Microbiology,

Institute for Research on Animal Diseases,

Agricultural Research Council,

Compton, Newbury,

Berkshire RG16 ONN, UK

The Veterinary Research Institute,

T. M. WHASZKA

Al Partyzantow 57,

24-100 Pulawy, Poland

Received June 20; accepted August 20, 1975.

${ }_{1}^{1}$ Caletti, E., Ristic, M., and von Lehmden-Maslin, A. A., Am. J. vet. Res., 29, $1603-1612$ (1968).

Tannock, G. A., Arch. ges. Virusforsch., 43, 259-271 (1973)

3 Mishra, N. K., and Ryan, W. L., Am. J. vet. Res., 34, 185-188 (1973)

4 Watkins, H., Reeve, P.. and Alexander, D. J., Arch. Virol., 47, 279-286 (1975).

5 Garwes, D. J., and Pocock, D. H., J. gen. Virol (in the press).

Floyd, R. W., Stone, M. P., and Joklik, W. K., Analyt. Biochem., 59, 599-609 (1974).

7 Duesberg, P. H., Proc, natn. Acad. Sci. U.S.A., 60, 1511-1518 (1968)

\section{Presence of factor VIII-related antigen in blood platelets of patients with Von Willebrand's disease}

Von Willebrand's disease (VWD) is an autosomally inherited disorder characterised by low factor VIII activity (antihaemophilic factor, AHF), prolonged bleeding time, reduced retention of platelets in a glass bead column and abnormal distocetin-induced platelet aggregation. The prolonged bleeding time in VWD has been attributed to the absence of a plasma factor, the von Willebrand factor (VWF), as shown by a correction of the bleeding time after infusion of normal and haemophilic plasmas ${ }^{1}$. Addition of purified factor VIII in vitro specifically corrects the abnormal platelet retention and ristocetin aggregation in VWD ${ }^{2-5}$, whereas transfusion of similar material into dogs with VWD also corrects the prolonged bleeding time (B.N.B., W. J. Dodds; J. A. van Mourik, J.J.S. and
W. P. Webster, unpublished). This led to the suggestion that factor VIII is closely related if not identical to VWF, although dissociation of factor VIII procoagulant activity from factor VIII-related antigen (F VIII-RA) is observed in certain conditions ${ }^{6,7}$. The plasma concentration of $F$ VIII-RA is usually reduced in VWD suggesting a reduced synthesis of factor VIII $(\mathrm{VWF})^{8}$. In contrast to this we now report the presence of normal concentrations of F VIII-RA in platelets of patients with VWD. This F VIII-RA supported aggregation induced by ristocetin in a washed platelet system ${ }^{9}$, a property of factor VIII which has been attributed to VWF activity.

Human blood platelets were washed according to the method of Karpatkin ${ }^{10}$. ACD-blood was centrifuged (10 min, $200 \mathrm{~g}, 20^{\circ} \mathrm{C}$ ). Platelet rich plasma was diluted in 5 volumes of Krebs-Ringer buffer ( $p \mathrm{H}$ 7.4) containing $9 \mathrm{mM} \mathrm{Na}_{2-}$ EDTA. After centrifugation $\left(15 \mathrm{~min}, 1,000 \mathrm{~g}, 4{ }^{\circ} \mathrm{C}\right)$, the platelets were washed once in Krebs-Ringer buffer containing $9 \mathrm{mM} \mathrm{Na}$-EDTA and twice in Krebs-Ringer buffer containing $1 \mathrm{mM} \mathrm{Na}$-EDTA. The platelet pellet was finally resuspended in Krebs-Ringer buffer containing $30 \mathrm{mM}$ glucose and $1 \mathrm{mM}$-amino caproic acid. In the final washing fluid the protein content was lower than $50 \mu \mathrm{g} \mathrm{ml}^{-1}$ (ref. 11), and the concentration of F VIII-RA, measured by electroimmunodiffusion was below $0.05 \mathrm{U} \mathrm{ml}^{11}$ (ref. 12). $1 \mathrm{U}$ F VIII-RA was defined as the amount present in $1 \mathrm{ml}$ pooled normal plasma prepared from 40 healthy subjects ${ }^{12}$. In the final suspension $\left(1 \times 10^{6}-3 \times 10^{6}\right.$ platelets $\left.\mu \mathrm{l}^{-1}\right)$ the platelets were disrupted by freezing and thawing (four times) fcllowed by centrifugation $\left(60 \mathrm{~min}, 30,000 \mathrm{~g}, 4{ }^{\circ} \mathrm{C}\right)$.

Ten suspensions of normal human platelets were tested. The concentration of F VIII-RA detected in the supernatant was $0.15 \mathrm{U} \mathrm{mg}^{-1}$ platelet protein (range $0.11-0.25$ ) or $43 \mathrm{U}$ per $10^{11}$ platelets (range 19-94). Expressed per platelet volume $\left(8 \times 10^{-15} 1\right)$ (ref. 13) the concentration of F VIII-RA was 60 times (range 21-156) higher than that in plasma. Similar values were reported by Nachman and $\mathrm{Jaffe}^{14}$.

Platelet F VIII-RA showed a reaction of identity with plasma F VIII-RA, when tested in immunodiffusion using a rabbit anti-factor VIII serum and the antisera raised against the low ionic strength components (ref. 15 and B.N.B., J. van Mourik, S. de G., J.M.H.-H. and J.J.S., unpublished). Cross-immunoelectrophoretic analysis revealed an electrophoretic mobility comparable with that of plasma F VIII-RA.

Howard et al. ${ }^{16}$ quantitated F VIII-RA on intact washed normal platelets and concluded that F VIII-RA was firmly bcund to the membrane fraction. A similar conclusion was reached by Bloom ${ }^{17}$ using an immunofluorescent technique. On the other hand, the localisation of F VIII-RA throughout the megakaryocytic cytoplasm is in agreement with its localisation inside the platelet ${ }^{18}$. Nachman and $\mathrm{Jaffe}^{14}$ reported the presence of F VIII-RA in subcellular membrane and granula fractions. We examined this localisation by a previously described indirect immunofluorescent technique $^{19,20}$. Suspensions of intact washed platelets were incubated with antifactor VIII in suspension, washed again, and incubated with fluorescein isothiocyanate labelled horse anti-rabbit globulin (Central Laboratory of the Netherlands Red Cross Blood Transfusion Service, Amsterdam). A drop of this suspension was studied under the fluorescence microscope. Most platelets were unstained, whereas a vivid granular staining was obtained after disruption of membranes by air drying of a drop of the same platelet suspension on a glass slide. The specificity tests have been described in detail elsewhere ${ }^{20}$. Staining with normal rabbit serum instead of with antifactor VIII was used as a control. The difference between staining in suspension or staining after air drying suggests that F VIII-RA is present inside the platelets.

In agreement with the results of Howard ${ }^{16}$ and Nachman and $\mathrm{Jaffe}^{14}$ no factor VIII activity could be detected in 